\title{
Another Possible World-Reading Yuezhi Zhao, Communication and Society: Political Economy and Culture Analysis
}

\author{
Yilian Zhang \\ School of Humanities, Jinan University, Guangzhou, China \\ Email: zhangyilian26@gmail.com
}

How to cite this paper: Zhang, Y. L. (2018). Another Possible World-Reading Yuezhi Zhao, Communication and Society: Political Economy and Culture Analysis. Chinese Studies, 7, 251-258. https://doi.org/10.4236/chnstd.2018.73022

Received: May 16, 2018

Accepted: August 14, 2018

Published: August 17, 2018

Copyright $\odot 2018$ by author and Scientific Research Publishing Inc. This work is licensed under the Creative Commons Attribution International License (CC BY 4.0).

http://creativecommons.org/licenses/by/4.0/

\section{cc (i) Open Access}

\begin{abstract}
Yuezhi Zhao is famous for her theory of communication criticism. In the western-dominated international academic circles, she is the first critical scholar of communication in mainland China. In her first Chinese monograph, "Communication and Society: Political Economy and Culture Analysis", put forward "look east, go south": open up a new perspective of communication research in the post-crisis era. While deeply worried about the influence of depoliticization and neoliberalism on Chinese society, she also hoped that China would be different from the development mode of western capitalism with patriotism, and put forward the insight that "another world is possible".
\end{abstract}

\section{Keywords}

Globalization, Communication, Introspection

\section{Introduction}

Professor Yuezhi Zhao is from Jinyun County, Zhejiang Province, in 1980 she admitted to the Department of Journalism, Beijing Broadcasting University (now the School of Journalism, Communication University of China), and graduated in 1984, in the same year, she admitted the qualification to study in Canada at public expenses. She began studying for a postgraduate degree in the Department of Communication at the Simon Fraser University, Canada in 1986, and obtained a master's and a doctor's degree in 1989 and 1996 respectively. She taught at the Department of Communication at the California University, San Diego, USA from 1997 to 2000, and returned to teach at her alma mater, Simon Fraser University, Canada, in September 2000. Since 2004, she has been a special 
professor in Canada for the political economy of global communication. She is now the youngest professor at the School of Communication at Simon Fraser University. Since 2009, she has been appointed as a Chair Professor of Chang Jiang Scholars in Education Ministry of Communication University of China. Professor Yuezhi Zhao has recently published two monographs, i.e. Global Communications: Toward a Transcultural Political Economy, Communication in China: Political Economy, Power, and Conflict and Communication and Society. an Analysis of political economy and Culture (China Communication University Press), and also three edited, dozens of academic articles in English and Chinese. In the paper Communication and Society: an Analysis of Politics, economy and Culture, from the perspective of critical communication, author makes a serious analysis to China in globalization and puts forward some unique and valuable insights. It brought us a lot of inspiration. In particular, the book criticizes the existing shortcomings in news communication in China, which hit the nail on the head, and point to the core problem. After reading this book, there are a lot of feelings so that I write this article.

\section{Introspection on Globalization}

\subsection{Introspection on Economic Globalization}

There is neither world economy nor economic globalization in the long course of human development before entering capitalist society. Since World War II, Economic globalization has been "organized", International Organization is the most important form in the process of Economic Globalization, Most countries take part in economic globalization through participation in international organizations, the principles, rules and decision-making procedures of economic globalization are also embodied through international organizations in the form of joint declarations or conventions. By whom is the constitutional system of international organizations established? What are the core interests? Scholars who oppose globalization believe that economic globalization is essentially "westernization" and "Americanization". They believe that economic globalization is a "trap" that developed countries have set for developing countries. Although this view is biased and extreme, it reveals the fact that there is unequal status and interests among countries in the process of globalization.

China finally entered WTO in 2001, the whole nation is great rejoicing. The benefits of economic globalization to China are obvious, China is able to make use of advanced technology and foreign investment, through foreign trade, to complete the process of industrialization urbanization in relatively short time. And the negative effects are also obvious. The scarcities of resources and environmental pollution in China have also deteriorated rapidly as a result of economic globalization. As a "world factory", China has benefited from economic globalization, but the huge export processing industry also puts heavy environmental pressure on China. Under open international economy, international trade and direct investment can "produce highly polluting products in 
low-income countries while consume them in high-income countries"1. At present, this is the basic relations between developing countries such as China and India and Western developed countries including Japan.

\subsection{Introspection on Technology Globalization}

For a long time, the Chinese government and people have "looked up" to technology from the West, They want to turn technology into tools and use technology to narrow the "certain gap" between China and the West. In 1955, McLuhan, a media scholar, criticized the media tycoon David Sarnoff, he said that media technology is the product of modern science, and it does not matter whether itself is good or bad, What determines its value is the way people use it. McLuhan believes that the content of media dissemination is only "meat buns which burglary used to divert the watchdog (Carr, 2010)." In the long run, media technology has had a profound impact on the way we think and behave, and the process is unnoticed.

Dallas Walker Smythe , a pioneer in the field of communication political economics, who studied China in the 1970s, found that many Chinese political economists, philosophers and politician believe that "craftwork and technology are autonomous and non-politicized." "They showed a kind of stubbornness and even rejected the possibility of discussing this issue at all." "There is no socialist road in the development of capitalist science and technology." Smythe said. He thinks Chinese manufacturing now employs capitalist technology, such as private cars, household washing machines, refrigerators, etc. Armed with these tools, Chinese families eventually are led to the cultural path of capitalism (Zhao, 2014: pp. 243-244). I think that's a bit of an incredible point but it's true. In recent years, China has invested heavily in information technology. To 200 million rural illiterate or unfed people, the development of information technology seems to be a distant dream. The gap between urban and rural levels of technological development is likely to widen.

\subsection{Introspection on Cultural Globalization}

Economic globalization brings us a phenomenon, it is thought that we're starting a new era, a world different from the world before. Under the new liberalism, everything is globalized. But can culture become a commodity for globalization? France is the first to propose "cultural exception" in the European Union".

Since the new century, economic globalization has promoted the global spread

${ }^{1}$ China's environmental pollution is rapidly deteriorating due to economic globalization. 21 st Century Business Herald. 2011-1-19.

${ }^{2}$ Cultural Exception (French: 1exception culturelle) is a political concept introduced by France in General Agreement on Tariffs and Trade (GATT) negotiations in 1993 to treat culture differently from other commercial products. Its goals are to point out that States are sovereign as far as limitation of culture free trade is concerned in order to protect and promote their artists and other elements of their culture. Concretely, it can be seen through protectionist measures limiting the diffusion of foreign artistic work (quotas) or through subventions distributed according to the country cultural policy. 
of capitalist consumerism cultural value system, relevant cultural conservation organizations have taken constructive at the policy level. In October 2005, the 33rd General Conference of UNESCO adopted by an overwhelming majority the Convention on the Protection and Promotion of the Diversity of Cultural expressions. In 2013, France asked the European Union to uphold its "cultural exception" position, which, in addition to excluding audiovisual areas from free trade negotiations, should be extended from traditional culture to digital ${ }^{3}$.

Although policies and proclamations have been issued, the concrete operation of power relations, the actual process of communication and cultural practice is quite another matter. Different expressers led by different positions and interests have different understanding even for the same concept. The non-commercial nature of culture is recognized by the international community, but how can it be protected? What culture is protected? When economic globalization promotes the spread of consumerism culture to the world, many national native cultures appear "weak". This is reality.

\section{3. "Look Eastward, Go South": Beyond the Hegemony of the Western Knowledge System}

\subsection{Epistemological Subversion}

"Look East, Go South" means to transcend the "central radiation" international communication research framework and issue setting thinking pattern with the west, especially regarded the United Kingdom and the United States as the origin, and to regard the increasingly active communication and cultural flows between the "East-South" and the "South-South" as important research topics (Zhao, 2014: p. 289). In her book, Yuezhi Zhao points out that "look east, go south" is not only geographical orientation, but also epistemological subversion of modern western hegemonic knowledge or power system.

In the book of Rise of the Global Left, Portuguese sociologist Boaventura de Sousa Santos puts forward the Southern epistemology. The main aim is to oppose neoliberalism and on this basis to advocate "global cognitive justice". In Santos' view, "global cognitive justice" is the epistemological basis of "global social justice", and there is no really "global social justice" without "global cognitive justice" (2006: 14) (Zhao, 2014: p. 281). Base on the whole world, not simply replace it with the West or the East. This means balancing development as far as possible, rather than focusing on the interests of a particular region or country.

\subsection{Transcend "Western" knowledge Rather than Reject It}

When we say that challenging Western dominant knowledge or power hegemony does not mean complete exclusion of any "Western" knowledge. In fact, in western academia, many critics have been engaged in the production of anti-institutional knowledge against dominant knowledge or hegemonic power

${ }^{3}$ Wangchun Liu \& Mei Wang. In the face of the strong American audio-visual industry, France takes the lead in maintaining the EU's “cultural exception" position. China culture daily2013-5-23. 
systems. Such as Polanyi's criticism of the market myth of so-called spontaneous regulation in his Great Transformation. He believes that this system of "society embedded in economy" is not only against human nature and natural world, but also will destroy the whole society. Such a system could not exist at any time unless the human and natural substances of society were eliminated; It would destroy humanity and turn its environment into a wilderness (Li \& Huang, 2012).

Many western scholars deeply and thoroughly criticize their own western society and pay close attention to the national liberation and social reform movement in the east and south. They have a vision in their hearts-to build another possible world and transform the present world. For example, Francis Fukuyama, a famous American scholar, suggested that America is in decay (America in Decay). Therefore, we cannot think narrowly and extremely that the knowledge of the West is squeezing and excluding the East. This simple logical attribution judgment is extremely arbitrary and is not conducive to global cognitive justice.

\subsection{Beyond Narrow Nationalism}

"Look East, Go South" means that we should transcend cultural relativism and at the same time surpass cultural essentialism related to the separation of eastern and western civilizations. We should oppose the idea of cultural diversity within the global capitalist system and consumerist lifestyle. Also we should be wary of joining the chorus of words such as "the rise of China" and "the rejuvenation of Chinese Civilization" at the level of zero-sum game and within the framework of narrow nationalism between East and West, especially between China and the United States (Zhao, 2014: p. 285).

From the macro point of view of the development of human civilization, the east-west division is originally the product of "Orientalism" criticized by Said (Said, 1978), which is a part of western colonial ideology and political, economic and cultural hegemony (Zhao, 2014: pp. 286-287). The other possible world is not a narrow, against present world, but a new one with tolerance, absorption, and correction.

\section{Chinese Communication and Social Reflections-Another Possible World}

In the process of the development of human society, Marx found the basic law of social development by criticizing the essential contradiction of capitalism. Marx did not criticize for the sake of criticism, but to discover and build a new world through criticism. In the same way, critical scholars of communication criticize imperial communication, nor is it to criticize for the sake of criticism, but to build a new world.

\subsection{Reflections on Chinese Media}

In China, the professional discourse construction of journalism practitioners is characterized by fragmentation and localization. Some journalists continue to 
pursue the relative independence of news. And the role of the media in supervision of public opinion has also been developed to a certain extent (Zhao, 2014: pp. 161-162). However, for various reasons, these supervision often only expose local scandals, only criticize surface phenomenon not deal with deep problems. Chinese media often report news only to their appearance, not excavate depth of information. The presentation of information is often a single angle and homogeneity.

From the current Chinese media reports and their underlying ideas, we can find that the Chinese media cannot really report on "China", nor report on behalf of the interests of the people. Neoliberalism and consumerism have permeated into the idea of a lot of media. This is especially true of the current online news media. The network news Medias is full of entertainment gossip information, lack of the corresponding guidance and echo to the mainstream values and mainstream culture.

\subsection{China Calls for Communication Scholars Who Have Critical and Introspective Spirit}

In Chinese academic circle, Scholars with critical and reflective spirit are not common, cynicism "scholars" are common. The story of Yuezhi Zhao, a communications scholar, can be a good example. She summed up her reasons for being "stigmatized": "first of all, I was a farmer, No intellectual ancestry. Second, my scholarship is not the same as that of others. I disturb the 'clear dreams' of other people. Third, in a male dominant academic world, I am still a rigid female scholar (Chen, 2013)." The knowledge field became the power field and the Vanity Fair.

At present, journalism and communication scholars also have different academic positions and orientations. In her book, Ms. Yuezhi Zhao points out, one choice is to continue the interpretation of the grand liberal theory in the field of Chinese journalism and communication, while attacking authoritarian and nationalist news dissemination, while seeking the democratic communication subject and the idealized "public field" in the "middle class" (Zhao, 2014: p. 38). Other choice is beyond the theoretical scope of simplification and formula to study the social distribution of liberation and oppression experience and the presentation of relevant media, to pay attention to and to explain the complex social interests and meaning demands of the people and their links and interactions with official ideology and discourse. The two choices of teacher Yuezhi Zhao undoubtedly have a positive impact on the development of news communication. They can break through the existing problems and barriers of news dissemination. But the process of realizing these two choices is not simple and easy. It needs to build and develop the internal and external environment together.

In her book, Prof. Zhao suggested, Chinese Communication circles call for Scholars with critical and introspective Spirit, They are neither historical nihilists, nor western parrots, nor "Chinese culture" essentialists or narrow national- 
ists. Although there is a top-down construction project of Marxist news communication theory in China, few scholars deeply combine with reality to carry out the construction of communication theory. As a critical and reflective propagandist, it is necessary to understand "Chinese culture" from the standpoint of criticizing cosmopolitanism and to critically sum up China's local knowledge in pursuit of socialism and the practical experience of the socialist movement in the world. On this basis, with epistemological imagination and democratic imagination, to find theoretical and practical resources for local and international dissemination of democratization. I agree with teacher Zhao very much. But how can there be such critical and reflective spirit of scholars, as mentioned above, it needs the proper cultivation and inoculation from the internal and external environment.

\subsection{Is Neo-Nativism Possible?}

Globalization and urbanization have made slums spreading on Earth at an unprecedented rate in history. How to introspect the urbanization process that China is pushing hard? As the birthplace of nation-states, Europe and the United States' history comes from the city-states of the Mediterranean. In the development process of Capitalism's different systems, its core and power is the city. The relationship between urban and rural areas in Chinese history is not operate as that in the West. On the contrary, China's urban-rural relationship is a process of nurturing each other (Lv, 2010). How can China continue to develop harmoniously? China must go her own way.

It is under this background that Xinyu Lv (2010) puts forward the concept of "neo-ruralism". Prof. Lv desirs to preserve the community and established cultural diversity, species diversity, biodiversity and diversity of the way of life of the villages, under this premise, to develop Organic Agriculture based on small Farmers, while making the countryside more suitable for human habitation, a new type of interaction between urban and rural areas has also been re-established (Zhao, 2014: p. 294). Neo-ruralism seems to run counter to economic globalization, it seems to run counter to the pace of historical progress. But it is a sustainable, harmonious development model. It is the inheritance and development of China's agricultural civilization for more than five thousand years, and is a tentative idea based on the national conditions of our country. It is a utopia and also a possibility of the future, which requires us to work hard with the spirit of criticism and reflection.

\section{Conclusion}

In this book, profess Zhao analyses the political economy and culture of globalization, she points out that the construction of China's modernization needs active reflection. We cannot follow the old way of other countries; we should find a way suited to our national conditions. In this paper, an example is given. Instead of blindly pursuing urbanization, combined with the reality of China, we should 
make great efforts to develop the countryside that is "Neo-ruralism". Only thus can we solve the social crisis faced by Chinese cities and rural areas while at the same time exploring the possibilities of changing the unequal pattern of the world (Lv, 2010).

\section{References}

Carr, N. G. (2010). The Shallows. What the Internet Is Doing to Our Brains. Chunyi Liu Translate. Citic Press Group.

Chen, N. (2013). Not to Be Self-Alienated Academic-Visiting Professor Yuezhi Zhao, Professor of Communication at Simon Fraser University in Canada. Journalism Lover, 6, 54-57.

Li, B., \& Huang, W. X. (2012). From Depoliticization to Politicization: Reading Yuezhi Zhao, Communication and Society: Political Economy and Culture Analysis. Journalism Bimonthly, 1.

Lv, X. Y. (2010). New Nativism, or Urban Slums? Open Times, 4, 115-135.

Zhao, Y. Z. (2014). Communication and Society: Political Economy and Culture Analysis. Communication University of China Press. 